This is a post-print version of an electronic article published here:

Kruger, E., Magnet, S., \& Van Loon, J. (2008). Biometric Revisions of the 'Body' in Airports and US

Welfare Reform. Body \& Society, 14(2), 99-121. http://doi.org/10.1177/1357034X08090700

http://bod.sagepub.com/content/14/2.toc

\title{
Biometric Revisions of the 'Body' in Airports and US Welfare Reform
}

\author{
Erin Kruger, Shoshana Magnet And Joost Van Loon
}

\section{The State of Exception}

Agamben defines the state of exception as a 'threshold of indistinction' that suspends law by differentiating what is included in the legal order from that which is excluded. The state of exception is, therefore, not a precise or identifiable kind of law (like the law of war), given that it suspends legal order and abolishes executive, legislative and judicial powers (2005: 6-7). Agamben's (1998) notion of the state of exception combines Carl Schmitt's (1985) idea of the sovereign and Michel Foucault's (1977) treatise on biopower to argue that the sovereign makes decisions concerning life and death.

Agamben (1998: 15) agrees with Schmitt's assertion that both the sovereign and the execution of political power are a consequence of 'the sovereign decision'. For Schmitt, the decision is the originary politico-legal structure, 1 since sovereignty and the sovereign do not exist prior to the decision but are constituted through it. The act of decisionmaking simultaneously creates the state of exception and invents the 'decider' (the sovereign). The sovereign is therefore always an ambiguous and paradoxical creature, since the sovereign exists inside and outside, as well as before and after, the order it governs. The structure of the sovereign paradox is the state of exception, since it differentiates what is included and excluded from legal order at the precise point that the sovereign decides on the exception. The state of exception is therefore a paradoxical threshold of indistinction - an interval or liminal space - that suspends law and destroys legal and political boundaries through the contradictory act of forging them. The state of exception is the principle of legal localization, since the sovereign decision opens the space by which a certain legal order and territorial formation become possible. Schmitt contends that the moment of the sovereign decision opens the spaces by which certain legal order and territorial formation become possible. This does not have to be only a physical location (e.g. territory), but can also refer to legal status, namely citizenship. The sovereign decision, then, creates and guarantees the spaces and situations law needs for its own validity (Agamben, 1998: 16).

Contrary to Schmitt's idea of the ordering of space as 'taking the land' (the determination 
of legal and political ordering), Agamben posits an idea of ordering space that includes taking the 'outside' (1998: 19). That is, Agamben disagrees with Schmitt that sovereign power operates by separating localization (territory) from order (the state), but instead argues that the sovereign power operates by destroying this very distinction between space and the state. For Agamben (1998), the most dangerous aspect of the state of exception is its capacity to define, create and produce spaces of exception where sovereign power may operate without legal restraint.

The concentration camp exemplifies the absolute space of exception where the link between localization and ordering is broken. For Agamben, the ordering of space refers not to the separation of localization (territory) from order (the state), but rather to their fusion. Agamben (1998: 170-1) uses the concentration camp to illustrate the most severe consequence of the intersection between territory and politics. The camp is a space that materializes outside of the legal order when the state of exception becomes permanent. The camp is, therefore, the ultimate space without law where questions of legality or illegality are irrelevant. The merging of territory and politics has determined the crisis of the old nomos of the earth and - according to Schmitt - resulted in the abstraction of principles of war from actual territorial conflict, and thus the possibility of perpetual war (Schmitt, 2003).2 Agamben (1998: 20) shows that Schmitt's earlier defence of despotic sovereignty (of the nation-state) has been made obsolete in the space of exception.

Sovereignty is inaugurated by an arbitrary act. The decision creates and guarantees the situation law needs for its own validity (Agamben, 1998: 16). Sovereignty is thus the power to establish the state of exception. In this way, the state of exception no longer occupies an extreme case of the unholy marriage between law and politics, but has instead become the rule. In reflecting on the aftermath of 9/11, Agamben concludes that the state of exception has reached its 'maximum worldwide deployment' by maintaining a 'threshold of indeterminacy between democracy and absolutism' $(2005: 3,87)$ with the extreme consequence of turning the 'juridico-political system' into a 'killing machine' (2005: 86).

Key to understanding Agamben's $(1998,2005)$ notions of homo sacer and 'bare life' is his concept of biopolitics, in which he reveals the relationship of his work to that of Foucault. For Michel Foucault (1977), starting in the 17th century, the 'old power of death' that characterized sovereign power was overridden by the administration of bodies and the calculated management of life. Instead of the sovereign decision to take life or let live, now, power over life seeks to foster or disallow life at the site of the individual and collective body. The simultaneous supervision of many bodies occurs through a form of politics Foucault calls 'biopolitics'. Now, the collective population becomes the unit of regulation and the individual body the basis of a new form of power he calls 'biopower':

For the first time in history, no doubt, biological existence was reflected in political existence; the fact of living was no longer an inaccessible substrate that only emerged from time to time, amid the randomness of death and its fatality; part of it passed into knowledge's field of control and power's sphere of intervention. Power would no longer be dealing simply with legal subjects over whom the ultimate dominion was death, but with living beings, and the mastery it would be able to exercise over them would have to be applied at the level of life itself. For the first time, biological existence was reflected in political existence; the fact of living was no longer an inaccessible substrate that only emerged from time to time, amid the randomness of death and its fatality; part of it passed into knowledge's field of control and power's space of intervention. (Foucault, 1978: 
Biopower is thus the founding premise for Foucault's notion of biopolitics, the growing inclusion of natural life in the mechanisms and calculations of power. Law constitutes bodies in a way that no longer relies on the sovereign method of clearly demarcating 'enemies' from obedient subjects, but that increasingly operates through the disciplinary 'norm'.

Like Foucault, Agamben $(1998,2005)$ has an interest in the relation of state control to life and the body. Following Foucault's notion of biopower and biopolitics, Agamben identifies the politicization of life in his notion of 'bare life' or 'sacred life', where the state's logic and regulative capacity is possible only through penetrating the biological realm of human life: '[L]ike language becoming fully comprehensible only in its immediate relation to people', so are law and life 'tightly implicated in a reciprocal grounding' (2005: 85). Agamben identifies the point at which the law and life meet at the site of the body as exemplified by the 1679 writ of habeas corpus. He argues that democracy is born "precisely at this assertion and presentation of the "body" - habeas corpus ad subjiciendum - known simply as "you will have a body to show" (1998: 124). Thus, modern democracy exists at the point where bare life becomes possible within every individual body- making the body what is at stake in political conflict. Democracy, for Agamben, responds to 'law's desire to have a body' by compelling law to assume the care of this body (1998: 124-5). Agamben concludes Homo Sacer by stating that the 'body' itself is always caught in a deployment of power, constituting the body as 'always already a biopolitical body and bare life'. The outcome is that 'law, fact, juridical rule and biological life' are no longer distinguishable (1998: 187). One could say that in the act of entwining law with biological life, law becomes life. In this way, the body is a living being at issue for politics as well as a space where politics are enacted.

The danger of a sovereign space is that it can only exist when individuals are 'outcast from law' (Agamben, 1998, 2005) and the possibility for 'bare life' occurs by creating a ban that sets the person outside of law and then abandons her. For instance, individuals in a concentration camp represent the extreme subjects of bare life, as they are held to have no concerns other than survival (Agamben, 1999). Moreover, prisoners in a camp can be tortured without consequences for the authorities responsible for their 'care' (Agamben, 1999).3 At the level of bare life, individuals are stripped of their political status (bios) and reduced to their biological status (zoe), 4 thus creating a space where state politics merge with biopolitics (Agamben, 1998: 171-4). Bare life and politico-legal rule become indistinguishable.

In his analysis of the state of exception, biopolitics and bare life, Agamben sets up critical relationships between law and life, and law and the body. In situating his notions of sovereignty, law and power on the premise that norms and rules function in relation to the body, Agamben asserts that the physical body has come to be regarded as the primary unit of state politics and law. As Agamben skilfully reveals the body-law relationship in varying contexts, his interpretations open up possibilities for theorizing the importance of biometric representations of the body. In this article, we extend Agamben to argue that law and the body are inseparable. We assert that biometrics5 are used to engrave law upon the body as they reduce the body to an identificatory signifier. This reveals every body's capacity for bare life - although every body does not carry this capacity equally. We 
examine the ways that biometrics operate in varying spaces outside of law in order to expand Agamben's notion of the state of exception, to consider what bare life might look like when the material body can no longer be assumed.

We consider two states of exception - airports and the US welfare system - in order to argue that these very different spaces are produced through the suspension of law as those held within them are deprived of juridico-legal personhood and reduced to bare life.

Revealing how different spaces render biometrics necessary by appearing to require new levels of subjectivity while simultaneously reformulating corporeal and digital images of embodiment, both the airport and the US welfare system rationalize and justify the use of biometrics under the rubrics of 'security' and 'fraud' and both are tied to risk. The airport is spatially unique in that it composes (in singular contiguity) both a 'space of place' and a 'space of flows' (Castells, 1996) that are linked by biometric capabilities to calibrate bodies. Here, biometric technologies are deployed to define and recognize 'security threats' in order to distinguish 'real' identities from false ones. As airports are simultaneously places of flows as well of rigid immobility, they demonstrate the ways that certain bodies are held fixed in the iron grip of the sovereign while the movement of others is facilitated. This process remains dependent on bodily identity.

While the airport is an excellent example of the collapse of space, politics and law given the ongoing 'war on terror', we also consider the more subtle intervention of biometrics in US welfare reforms that preceded the September 11 attacks. Welfare in the US uses biometrics primarily in an effort to prevent fraud. The targets of these biometric technologies are contained under the rubric of 'welfare recipients'. In this way, biometrics are mobilized to deliberately suspend some members of the state from inclusion into the law (e.g. human rights). Thus, in requiring welfare recipients to be biometrically fingerprinted, those who refuse to be biometrically identified are no longer eligible to receive basic sustenance - neither enough food nor a place to live. As such, they are placed outside of law and abandoned. Agamben asserts that bare life is defined by those who may be stripped of the right to survival without any ramifications for those entrusted with their care. We will show that biometrics are used to produce subsistence existences for welfare recipients in ways that reveal the legality or illegality of this phenomenon to be irrelevant. By examining these two 'exceptional spaces', we seek to understand how the bodily revisions that emerge under these new modes of biometric monitoring challenge Agamben's notions of 'bare life' and the state of exception.

\section{Introducing Biometrics}

In analogue and non-automated ways, biometric technologies have existed for centuries.

Parts of our bodies and aspects of our behaviours have historically been used as means of identification. We remember and identify people through facial recognition, voice recognition and signatures, all of which are established methods of authentication in banking, legal contracts and secured enclosures. Referring to the automatic recognition of people based on their distinctive anatomical (e.g. face, fingerprint, iris, etc.) and behavioural (e.g. online/offline signature, voice, gait, etc.) characteristics (Zhang and Jain, 2006: vii-viii), biometrics are deployed in various settings to verify that people are 
who they say they are ('one-to-one' matching) or to identify unknown people ('one-tomany' matching). In the case of identifying 'unknowns', biometric data are scanned against large databases to find a match (Feldman, 2003: 655).

Regardless of the biological feature under scrutiny, biometric systems operate by translating information about human features into mathematical constructions. The mathematical construction has no physiological or biological meaning. Rather, the information developed by the computer is indirectly related to physiological features (Feldman, 2003: 656). Current automated biometric systems are based on developing mathematical formulae to detect statistically significant correlations among the elements of abstracted patterns of human characteristics. For example, if one deployed iris recognition systems to identify an individual or verify their identity, this requires extracting a mathematical representation of the iris of a sample of the population. The representation would not be an actual image of people in the database, but a twodimensional representation of the elements of irises. Once the pattern information has been extracted and stored, analysts run computer analyses of the data to find the relationships in the patterns that would consistently allow differentiation of individual irises from the group. The formula, or algorithm, would provide the basis for determining whether the iris of the person requesting access has a high correlation with the iris of the person enrolled in the system. In this example, then, security goes well beyond riskmanagement as it inverts the latter's minimalist approach (risk-avoidance) to an affirmation of positivity. That is, since biometric systems depend on algorithms that analyse abstracted pattern representations of human characteristics, risks now provide opportunities for security. Biometric technologies are thus central to data-mining processes that both manage and produce the 'risk society' (Beck, 1992) as it is currently evolving into a fully digitalized telematic assemblage of 'securing'.

Biometrics differ from other identification technologies in that their advocates argue that they are able to strip the body down to its 'essence' or code - as if biometric bodily identifiers were a form of digital DNA. Yet, rather than being the blueprint for life, biometric industry representatives claim that these representations of the human body are maps of identity. However, unlike tattoos or badges, biometrics are not grafted onto the body. Rather, the aim of the biometric number is to strip away the flesh and represent the 'bodily essence' beneath. Thus, biometrics are not like the tattooed number imprinted on the body of concentration camp inmates. Nor do they adorn the body like the pink triangles or yellow stars used to identify the queers and Jews of the Third Reich. Rather, biometrics are imagined to be part of the project of uncovering the body's 'true' essence. As people are reduced to their biometric essentials, we see dramatized Agamben's assertion that every body contains within itself the capacity (or code) for bare life. In this way, biometrics become the technological facilitators of a process of ongoing bodily reorganization. They aid the production of modes of embodiment aimed at managing and regulating individuals through a process of sterilization that necessarily conceives of the 'body' in terms of identification and the elimination of 'matter out of place' (Douglas, 1984).

We now turn to the case of airports in order to consider how biometric technologies are used to transform mobile subjects into static objects. Next, we examine in detail the ramifications of biometrics for the immobile as our second case study analyses the 
development of biometrics for those bodies who are held motionless by poverty in the US welfare system.

\section{Airports}

The reason airports are effective in sterilizing their environments is that they are often seen as fully congruent with their idealized 'representations of space' (Lefebvre, 1991: 38-9). That is to say, airport architecture has internalized, from the outset, the 'state of exception' (Agamben, 1998). Only at airports would privileged individuals allow themselves to be submitted to such a stringent set of screenings and tests in exchange for being granted permission to travel. (As we will see, this is in contrast to welfare recipients, who are used to succumbing to these types of rigid technological examination on a daily basis.) Airports reveal that our so-called 'right to mobility' is framed by a continuous surveillance of movement as well as a range of 'stop-go' operations performing identity checks (Fuller and Harley, 2004). Far from suggesting that the distinctive role of the airport in securing mobility derives solely from its specific technological infrastructure (information architecture), we want to argue that its efficacy as a system of 'securing' stems from its ability to produce subjects of 'bare life' that are reformulated by biometric manipulation. Both the airport and the welfare system are at once legal, technological, social, military and cultural spaces that function at the threshold between politics and law, and operate at the site of the body. Examining the airport from a biometric point of view also reveals a more 'banal' state of exception (which is different from the concentration camp or Guantanamo Bay), as we accept our exposure to the technological operations in various procedures of normalization that seek to differentiate between 'safe' and 'risky', the latter becoming the standard against which the former must be secured.

Airports can be thought of as encompassing two forms of juxtaposing spatiality: as 'static places' and as a 'series of flows'. In Aviopolis (2004), Fuller and Harley refer to airports as 'laboratories' of socio-technical innovation. These innovations exert control, from crudely categorizing and grouping people into segmented spaces to far more sophisticated modes of profiling that operate on molecular and sub-molecular levels. They refer to airports as being unified through a distinctive 'information architecture' that is designed to regulate mobility. In this way, airports may be distinguished from the US welfare system in that the latter arguably embraces biometrics in order to regulate those who are already immobilized. The point is not that airports deny the outside world, but that they sterilize all operations to speed up and smooth the flows of people moving through any given airport. In an overview of airport architecture, Pearman (2004) describes airports as 'landmarks'. Indeed, unlike the spaces produced for the urban poor, airports are often prestigious architectural mega-projects, which the world's top architects compete to design. Apart from the sign value of airports (indicating that already, as early as the 1960s, this was at least as important as the 'exchange' and 'use values' of these distinctively modernist facilities), there are also substantial practical issues involved in airport architecture and design.

Airports can also be conceived as 'techno-hubs' that function to accelerate flows through their unceasing drive to limit contingency and ambiguity. The concept of 'techno-hubs' 
refers to spatial domains which provide an intensive entanglement of human, technical, symbolic, legal, administrative, military and commercial processes that are all involved in channelling, exchanging, directing and capitalizing on flows, especially risk/opportunity flows. Techno-hubs are often somewhat misleadingly called non-places (e.g. Augé, 1995), because their spatiality is never singularly organized around a specific set of differentiated functions or locatable identities (indeed they are spaces that are not tied to any particular place).6 Spaces marked by such threshold conditions are notoriously fragile and prone to outbursts of maximized anxiety and panic. Paradoxically, they are resilient in terms of their ability to sustain themselves as 'organized' spaces. This, we want to suggest, is because techno-hubs are not empty vessels but are perhaps best understood as complex life forms. Augé's 'mistake' of referring to airports as non-places comes from the fact that his anthropology of hypermodernity still engages with an essentially modern humanist notion of sociality, one that requires a sense of univalence (Castells [1996: 400] calls it contiguity) between locality and identification. More specifically, it engages a concept of social ordering that fails to acknowledge the primacy of flow and systemicnetworked forms of intelligence and communication.

If we think about airports as encompassing both places and non-places, they can also be conceived as containing 'spaces of flows' and 'spaces of places' (Castells, 1996). The airport as a 'space of flows' links our existence to forms of transit that are deterritorialized, commodified, institutionalized and externally governed. This vision is incompatible with the idea of the primacy of settlement in everyday life. As Castells (1996) reminds us, the 'space of flows' (which is perhaps a more accurate label for transit spaces than the designation 'non-place') is neither accessible nor relevant to everyone.7 Techno-hubs, like airports, are systems built on information architecture that have the capacity to extensively integrate (as well as separate and exclude) both digital and molecular flows, what is otherwise called 'logistics'. They are primary means through which a whole section of the world population is able to expand its radius of action and connect to the global 'network society'. In this way, airports may be distinguished from other spaces in that they exist exclusively to differentiate mobility. This is an originary purpose that is not entirely at odds with the origins of the US welfare system, which is designed to limit the sphere of action of the poor, to confine them to certain spaces, thereby naturalizing the inequities that are endemic to capitalism. Confinement is a means of preventing outbursts of domestic instability and migration.

The French modernist Le Corbusier (1971) famously conceived an almost organic image of the city as a system of horizontal flows and vertical sedentation (with the 'station' right in the middle). Airports, however, engage both horizontal and vertical flows, which - to keep faithful to the kind of modernist aesthetic espoused by Le Corbusier's vision had to be kept separate at all costs. Different flows are not to be mixed. This was a principle already central to Victorian household design and applied not only to sewage, water, and later gas and electricity, but also to the separation of house owners and domestic servants (Roderick, 1997). Similarly, we see that airports are constructed on the strict separation of flows of people (staff and travellers, people handlers and baggage handlers, etc.) and goods. Simon Charlesworth's excellent Phenomenology of Working Class Experience (2000) shows how life outside the space of flows (of disembodied being) is grim and breathes an ethos of entrapment, resentment, repetition and immobilization. The fact that very little of that messy lived world 'outside' interferes 
with the logical operations of techno-hubs suggests that the modern forms of blasé sociality described by Simmel (1948) have indeed taken precedence over the preceding ethos of situated morality (or mutual interpersonal recognition as the inauguration of social being). 8 Airports are, in effect, complex hubs where nearly all existing global flows (goods, people, finance, symbols, information) come together. Airports as a paradigm illustrate the ironic situation of having no space of flows without a space of places against which it is set. By way of comparison, the US welfare system exists as a space of places with only the barest possibility for flows. There are flows of course, mainly of information, but only rarely of people.

\section{Airport as a 'Space of Exception'}

While Agamben focuses on the 'camp' as the ultimate space of exception, we consider the airport generally, and the detention centre specifically, as logically connected 'spaces of exception' - albeit less extreme ones. The paradoxical mixing of multiple centres in airports constitutes the uniting of security spaces that both confuse and extend Agamben's notion of a singular, permanent space for the state of exception. It is the complex interrelationship and unique juxtaposition between 'spaces of place' and 'spaces of flows' that constitutes a threshold of indistinction in the airport. The addition of biometric technologies widens the range of spaces - both for airports and for the welfare system where 'bare life' is produced as a corporeal entity under realized and emerging security agendas.

Upon arrival (or departure) to (or from) a country, the individual is ascribed one of many identity categories: citizen or non-citizen (immigrant, refugee, refugee claimant, foreign national, traveller and so forth) (Bleich, 2005). After the September 11 attacks and the subsequent legislative provisions of immigration and refugee acts in Western countries, however, the immigration status of noncitizens is increasingly susceptible to overlaps with the political categories of 'terrorist' or 'terrorist suspect'. 9 In some cases, blurring these categories constitutes the larger identity category of 'threat to (national) security' (Shamir, 2005). Pratt (2001) refers to this as immigration penalty, a form of regulation that constitutes and enforces points of entry, polices non-citizens, identifies those deemed dangerous, deceitful or, as with the case of welfare, destitute, and refuses them entry or casts them out. The point of entry - in this case, the airport - is the nexus of national and international space through which the fusion between immigrant status and politico-legal identity constitutes the overarching category of 'security threat' and lays the foundation for the establishment of 'bare life'.

Consequently, designating individuals as 'threats to security' is a security measure with bodily consequences. Labels such as 'security threat' are powerful identity categories that result in the casting out and banishment of individuals from the general airport space to the isolation of the detention centre (see Butler, 2004: 50-100).10 The discursive construction of 'security threat' creates the bodily prerequisite required for a version of 'bare life' to emerge. Regardless of whether a crime is committed, the detained subject or detainee in the detention centre is not granted a specific sentence but can be held indefinitely based upon the expediency of security and immigration review processes. As with the biometric testing of welfare recipients, and unlike individuals in prisons who 
have been judged and sentenced through legal channels, holding 'detainees' under the premise of 'security threat' is justified as 'preventive' or administrative detention. The detention centre is thus a 'lawless space' where individuals are arrested and detained without having been accused of any particular crime.

Contrary to the flowing, channelling and directing capacities of the airport space, then, the detention centre is a permanent space of exception in which individuals are immobilized, invoking absolute, spatial parameters between 'insiders' and 'outsiders'. While the airport is a spatial threshold that maintains some legal oversight, the detention centre is a lawless space where administrative and executive functions rule. The paradoxical space of the airport is apparent when politics, laws and bodies merge to formulate specific spaces (e.g. the detention centre) and create distinct subjects (e.g. 'security threats'). It also reveals how, much like the US welfare system, the intersection of airport/detention spaces produces a politico-legal system based on accusation, confinement and the restriction of human rights, which is nonetheless devoid of any sole, central authority. Indeed, it reveals the fundamental arbitrariness of the sovereign decision which inaugurates the state of exception and actualizes it in the space of exception.

Detention centres in airports represent a version of a lawless space where bare life is not only constituted, but also serves as a prerequisite to further bodily scrutiny.11 Biometric technologies take the 'corporeal body' assumed to sustain the meaning of 'bare life' and integrate bodies of 'suspects' or 'the accused' into the flows and networks of airport culture through specific information systems such as iris scanning, digital fingerprinting and facial imaging technology. Digital fingerprinting, for instance, is a real-time procedure that transfers fingerprint information from airports to federal police and security agencies for an immediate security check. Some airlines have also implemented iris recognition technologies for their employees to prevent airport entry by unauthorized persons. Using infrared light to identify and create statistical abstractions of patterns in the coloured tissue around the centre of the eye (Feldman, 2003: 661), iris recognition is considered the most accurate way to produce pattern matches, since the iris (unlike the retina) does not change from the time a person is one year old (CBC online, 2004: 2). Likewise, in 2004, all Australian international airports implemented passports using facial recognition technology for airline crews (Zhang and Jain, 2006: viii). Such facialimaging technologies reduce facial qualities to mathematical abstractions that can be captured and evaluated electronically. The term 'Eigenfaces', for example, refers to a broad class of algorithms that represent and compare individual faces by reference to images of archetypal faces (Feldman, 2003: 658).

Operating outside consciousness or subjectivity, biometrics are able to continually engage in observation, surveillance, scanning, patterning, modelling, matching recognition and calibration. Under the dual aegis of security and efficient traffic management,12 passengers, threats to security and even airport employees are increasingly conceived through a series of pattern matches in the expanding database of airport life (see Fuller and Harley, 2004: 79; Salter, 2007). The biometric version of 'bare life' produced in airports corresponds to Deleuze's (1995) 'society of control', where the subject is not a corporeal individual but a 'data-subject'. For Deleuze, authority operates through digital and numerical channels in control societies, and individuals therefore no 
longer move physically from one closed site to another (as in Foucault's [1977] disciplinary society). Rather, they are increasingly subject to free-floating, nomadic forms of control that operate according to a 'numerical language' (also referred to by Deleuze and Guattari [1987] as 'nomos' and 'cipher') and re-conceive the individual and the mass based on access or denial to information: individuals become 'dividuals' (data representations) and 'masses' become information banks.

Reconfiguring the body into flows and networks that move through computerized, digital and virtual spaces reformulates the meaning of embodiment by redefining the individual through the increasingly sophisticated 'weaponry of information and communication networks' (see Amoore, 2007; Amoore and De Goede, 2005; Virilio, 1997). Unlike the 'traditional' state of exception that operates in physical spaces, the airport contains a variety of spaces that govern individuals at many levels: the intact, corporeal individual; the body part; and simulated, mathematically abstracted, computerized simulations of these body parts. Biometric technologies reframe the individual by anatomical features that are translated into algorithms, formulae and statistics, creating a state of exception that operates by time-distance, and through the speed of transmission (see Adey, 2007; Powers, 2002). Biometric spaces are fluid, flowing and decentred, operating through the transmission of information by way of communication networks and media technologies.

Biometrics (con-)fuse notions of identity by transforming discursive and corporeal meanings of the body into 'sterilized' visions of body parts. In airports, the transition in subjectivity from 'security threat' (the forging of foreign national status/terrorist identities) to detainee is not only a political designation, but also a technological one. The multiple transitions involved in bodily reorganization for 'bare life' to become both permanent and instantaneous occurs when the state of exception is no longer confined to a physical space, but also encompasses the digital spaces that produce dehumanized and malleable data-based subjects, which, thus constituted, are perhaps better described as 'tra-jects' or objects-in-flow (Virilio, 1997: 120). An interesting side effect of this biometric sterilization is that, inside airports, one is 'guilty until proven innocent' (this has obvious resonances with welfare provision as well), even though 'the categories of guilt expand constantly' (Fuller and Harley, 2004: 44).

Airports are thus sites where one can study emergent 'organizations' of riskflows (Van Loon, 2002) that centrally evolve around the interfaces characteristic of socio-technical systems. They are remarkable zones where globalization processes can be observed in situ and in real time. They are also technologically extremely dense and are in many ways 'frontiers' of technological innovation (often with close links to military technologies). Airports are full of media technologies, traditional as well as so-called new media; they are the emblematic spatial manifestation of connectivity. The recent biometric focus on obtaining physiological and behavioural profiles claiming to represent individual identities constitutes airports as hubs of identification processes, which - in the light of emergent technological couplings of databases and various forms of biometrics - entail an increasingly widespread domain of surveillance and control which is primarily driven by an emerging security agenda and the consequent cultures of fear. We turn now to the US welfare system in order to examine the ways in which biometrics are deployed to widen this sphere of surveillance and produce poverty as a state of exception. 


\section{The US Welfare System}

Airports engage in perpetual operations of sterilization and flow-management. The US welfare system has also been reformed to create a 'parallel digital space', where identities are processed as data and subsequently sterilized in order to separate the 'purely informational' from the ambiguous and dense messiness of everyday life. The system of welfare provision, especially in the US, has been developed alongside modes of surveillance and control that are also used in other disciplinary settings, most notably the prison system. In this sense, like airports, welfare entails a dispositif of 'technologies of sterilization' that helps to format 'biometric subjects' (rather than corporeal subjectivities, which entail a sense of self-recognition). These subjects only qualify for welfare support after having successfully passed the various 'security checks' which are de facto identity checks.

Introduced to welfare under the auspices of fraud prevention, biometrics in the US welfare system derive their logic from technologies initially designed to regulate crime, and thus have their roots in technologies of criminalization.13 In addition to capitalist logics (Gates, 2004), the rationale behind this transition from the prison system to the welfare system is that biometrics produce subjects who can be tracked easily by the state.14 Digital fingerprinting methods used for the identification of welfare recipients are identical to those used to verify the identity of prison inmates (Adelson, 1994). In this way, we see dramatized Foucault's assertion that prisons look like schools look like hospitals look like factories as the boundary between the 'prison-industrial-complex' and the welfare system blurs (Kohler-Hausmann, 2005) into a zone of 'indistinguishability'.

\section{The Spaces of Welfare}

The US welfare system adheres to a very different 'spatial logic' than that of the airport. The airport is characterized by various successions of stop-go operations and checkpoints (e.g. for 'identity checks'), as well as the more continuous 'surveillance' and tracking of movement that airport flows enable and maintain (Eubanks, 2006). It is quite widely accepted that, at airports, everything is a security risk and the history of aviation has shown that the number of security risks always expands. In contrast, the US welfare system as a governmental entity is spatially unique, operating through a series of offices where welfare recipients must biometrically present their bodies in order to qualify for and receive benefits. Unlike airports, welfare is not targeted at the already-mobile, but at those bodies held fast within the grip of the sovereign. To this end, biometric technologies are mobilized to further contain and confine already-imperfect forms of mobility. Thus, the receipt of welfare becomes a practice through which the welfare recipient is codified, identified and criminalized in ways that discipline, regulate and identify them as 'matter out of place' and then contain him or her.

The welfare system is a useful point of comparison to airports in that they demonstrate the way that those at the margins of the state are at greatest risk of being cast as juridicolegal non-persons. Thus, welfare recipients are at greater risk of becoming outcasts from law. In her article on sexual regulation and the US welfare system, Anna Marie Smith (2007) offers a feminist critique of Agamben in arguing that, while every body has the 
capacity for bare life, some bodies are more likely to be reduced to a life of subsistence than others. To demonstrate the increased vulnerability of some people to the state of exception, Smith foregrounds the bodies of welfare mothers and the ways that they are more likely to be subject to the conditions of bare life. Highlighting the 'neo-eugenics' policies that deprive welfare mothers of the most basic of human rights, Smith reveals that women on welfare are regularly subject to extreme forms of bodily invasions including:

... forcing the welfare mother to cooperate with child support enforcement - even if she is fleeing from a violent biological father - [she may be] order[ed] to disclose her sexual history, and to open her home, the personal conduct of her teenage children, and her very DNA structure to intensive governmental scrutiny. (Smith, 2007: 7)

Biometric technologies facilitate the process of casting welfare recipients into the state of exception. In denying those who refuse to be biometrically fingerprinted access to basic benefits, biometrics are ruthlessly deployed by the state in order to produce welfare as a state of exception. Welfare recipients - a group in which people of colour and people with disabilities are over-represented (Roberts, 2002; Rogers-Dillon, 2004) - are cast out of juridico-legal personhood if they will not have their biometrics encoded into a state database. Thus, in those states that require biometric authentification for the receipt of benefits, those who do not comply become unable to receive even basic sustenance and are reduced to bare life. Deprived of the right to food and housing, those welfare recipients that will not be biometrically authenticated become bodies that may be killed but cannot be sacrificed/murdered.

The risks of biometrics technologies are poignantly witnessed in people with mental disabilities, particularly those living with anxiety disorders. Individuals living with forms of acute paranoia find biometric fingerprinting technologies extremely frightening, often resulting in these individuals dropping out of the welfare system rather than surrendering their fingerprints (Monsebraaten, 1996).16 Thus, the example of welfare reveals that, although every body has the capacity for bare life, it will not be actualized in all of them equally; rather that this is a place to which certain bodies are more vulnerable.

The case of the US welfare system succinctly demonstrates how the state of exception 'becomes the rule' when biometric technologies are used to facilitate the sharing of information between diverse state bodies, including law enforcement and welfare agencies. Thus, in 1995 in Massachusetts, then-Governor Weld proposed sharing the prints taken for welfare authentication with the criminal justice system: 'Weld's plan would also go further than current law by allowing law enforcement officials investigating crimes to subpoena welfare fingerprint records' (Wong and Phillips, 1995). The demand that welfare recipients be biometrically fingerprinted, even though there is no law to govern this exceptional act, firmly places welfare recipients outside current law without ramifications for those responsible for their 'care'.

\section{Implementing Biometrics: Making Welfare Scientific}

Biometric identification makes the business of determining who qualifies for benefits appear scientific, regardless of whether or not this stated aim is accomplished. 
This gives the appearance of legitimating welfare reform through the apparent reduction of caseworker discretion and the perceived increase in accountability to governmental rules and regulations (Rogers-Dillon, 2004: 58).17 Using biometric technologies helps to achieve this goal by producing an 'objective' scientific image purporting to be 'the only true form of identification' (Yew, cited in Steinberg, 1993: 6). Replacing the discretionary eye of the caseworker with the allegedly neutral eye of technology, the biometric systems used in the US welfare reform project the image of rationality, efficiency and effectiveness (Stone, cited in Rogers-Dillon, 2004: 3-4). Under the rubric of 'improvement', biometrics only need to appear to make the welfare system more efficient and more scientific. 18 As a result, mandatory biometric fingerprinting continues to be widespread for welfare recipients, reminding us that welfare recipients, like those moving through airports, have become guilty until proven innocent.

In this way, these practices used to sort out the deserving from the undeserving poor (Gilliom, 2001), while claiming increased neutrality as they are moved out of the hands of social workers and into the scientized practices of biometric identification, entrench the 'state of exception', enabling the visualization of an ever-expanding list of bodies to be contained, deciphered and organized. Hypostatizing 'bare life' or zoe at the expense of bios (political life), zoe becomes increasingly susceptible to forms of state power. Moreover, through the process of normalizing the intrusion into those spaces where bios might previously have been claimed, the intensification of state power increases the number of spaces where the 'state of exception' may be claimed. Thus, the 'state of emergency' becomes quotidian and serves to legitimize the operation of the exception as the rule. 19 The sterilization processes associated with this technology and the data it produces is, in our opinion, another essential parameter of the way in which human bodies are induced into a 'state of exception' that does away with the corporeal individual and substitutes a 'mathematical abstraction' or 'data double'. The consequence is a denaturalization of welfare recipients resulting from anatomical characterizations produced through biometric scrutiny that leave them at greater risk of being criminalized in an ever-shrinking (in a double sense) social security/safety net in the United States.

Welfare, Biometrics and Bare Life

Prior to the implementation of biometric technologies by the US welfare system, welfare recipients were conceived of by virtue of their socio-economic status in addition to the categorizations of gender, race and disability. The use of biometric technologies has expanded and diversified the ways discrimination stigmatizes welfare recipients, right down to the microbiological level. Before the implementation of biometric technologies, the 'welfare recipient' already coincided with Agamben's (1998) notion of bare life: cast into a permanent state of exception in which, despite the lack of financial benefit to the state, their bodies were fixed into immobility by the intersection of their identities. 'Bare life' already exists for welfare recipients due to their status as 'poor' and is structured in full dependency on the government for 'survival'. As well, somewhat in contrast to the generic designation of 'terrorist' or 'security threat' found in the spaces of airports and applied to all travellers, the US welfare system performs a more discriminatory association between 'criminality' and 'welfare' in order to lay the foundation for the 
digital extraction of data profiles that characterize biometric intervention.

The bodily consequences of biometrics within the larger US welfare project are that they enable a larger range and series of classifications about who can be demarcated as a 'criminal' body and, therefore, who can be most easily tracked and kept under surveillance. The 'state of exception becomes the rule', in this case, when welfare recipients' bodies are digitized and stored in electronic databanks to be extracted, analysed or transmitted over state lines, as well as across international boundaries. Rather than the stated goals of eliminating fraud and facilitating the provision of benefits, biometric identification makes those already vulnerable to state surveillance further subject to monitoring at the level of electronics, mathematics and statistical profiling methods (Lyon, 2003, 2007). In this way, we see the ways that both the space of the airport and the space of welfare serve to inscribe particular bodies as unruly, as forms of 'matter out of place'. In refusing those who will not be biometrically identified even the barest subsistence from the state, the poor are produced as subjects of 'bare life'.

\section{Conclusion}

In our examination of biometrics, we see that these technologies are applied to individual bodies in a series of extractions and reconfigurations that violently reduce whole bodies to body parts and reassemble them as 'data' cases. This regime of techno-biopower, despite protests to the contrary, makes more than a gesture toward criminalization, dehumanization and exclusion. In our analysis of airports and the US welfare system, we revealed the ways that biometrics are deployed in order to reduce vulnerable bodies to 'bare life' (Agamben, 1998, 2005). Biometric technologies utilized in airports and the US welfare system - far from being race, gender, class or (dis)ability neutral - have instead technologized and thus facilitated the manipulation of marginalized bodies by coercive forms of power. Agamben defines 'bare life' as the corporeal condition of being cast out of or banned from law - we argue that biometric technologies facilitate this process and help to sustain the 'indefinite' suspension of law. Since data profiles are radically different from the corporeal individual, this makes traditional legal privileges, such as human rights, due process and the rule of law, irrelevant and unobtainable.

The biometric profile also raises questions concerning the ability to challenge false or mistaken readings of digital representations of individual body parts and features. Success in challenging biometric classifications also depends on the intersection of identities, since some bodies are deemed more trustworthy than others. Supported by 'hard science', biometric technologies now overshadow human rights and, increasingly, law itself. Once captured in an electronic database, data profiles are transported outside of law, where legal protections no longer apply. Delineating the space between 'informatics, biologics, and economics' as they intersect at the site of the body increases the potentially dangerous consequences of these technologies to already 'vulnerable citizen-subjects' (Haraway, 1997: 2).

Agamben claims that (bare) life post-9/11 exists in a perpetual state of emergency. Through biometrics, biopower is deployed on a micro-physiological scale at which bodies not only lose their corporeality, but also their individual rights and integrity. The 
language of human rights has no impact because it operates at the wrong level of analysis. Once computerized, the biometric data can be analysed and re-analysed, making the biometric profile a 'threshold of indistinction'.

The airport and the welfare system are oppositional domains as far as socioeconomic spatial stratifications are concerned. Yet these spaces are united through their common use of biometrics to produce bare life. Just as scientists in a laboratory perform experiments, airports are sites of analysis for social engineering and welfare recipients are the guinea pigs. New concepts for social ordering and intervention can be experimented with at airports without much resistance because they are permanent spaces of exception. When the technologies have been finetuned, they can be set to work in other systems, such as welfare, because, there too, the state of exception is the norm.

Hence, ways of discriminating and categorizing on the basis of race, gender, class and disability have not disappeared. Instead, they are multiplying as the ways to analyse, store, process and conceive of the body are reconfigured through biometrics. Biometric functions, such as data-mining and pattern-matching, will continue to develop and reorganize categories at increasingly sophisticated levels. In place of categories based on discursive, historical and narrative constructions, biometric categories are transient, everchanging and instantaneous. This is a new regime of social spatialization (Lefebvre, 1991), in which appeals to 'rights' and 'entitlements' become obsolete as the needs of the corporeal body are displaced in favour of the infinite manipulability of its digital double. Consequently, the introduction of biometric technologies into airports and welfare systems resembles a form of 'profound social death' (Patterson, 1982), where the 'bodyas-self' or 'person-as-body' no longer applies. Rather, the digital extraction of information from body parts, fragments and substances facilitates a de-personalization or de-humanization effect that enables security regimes to collect, analyse and disseminate information by depoliticizing the body and denying its sociality (Sharp, 2000).

Biometrics both challenge and confirm Agamben's state of exception. Using biometric technologies as a starting point, 'bare life' becomes digital and spaces of exception become the norm. While 'bare life' adequately describes detainees in airports, or those living on welfare in the US, we see how biometrics help to expand Agamben's thesis. Bare life, for Agamben, refers to a form of living that is strictly biological. It is thus at the point where life is defined by physiology alone that biology is captured digitally. Bare life is a state of living 'outside of the law' and 'without rights'. Biometrics is a form of governing the 'bare' against their will and, at times, without their knowledge. This means that the proliferation of biometrics increases the cases of 'bare life' - creating the reallife, real-time syndrome of the 'exception becomes the rule'; the exception, in this case, is the eradication of the biological body and the substitution of biometric profiles in its place.

Biometric reformulations of the body, then, emerge as the language of human rights; habeas corpus and due process are abandoned. Regulative power now operates by extracting information from the corporeal. Embodiment is being reconfigured by biometrics through a doubling of its own unique particularities and those of datagenerating, processing, monitoring, selection and application. This is Deleuze's prophetic society of control (1995) - one which has both supplemented and reconfigured disciplinary society. 


\section{Notes}

The authors would like to thank Neil Turnbull, Robert Smith and the anonymous reviewers for their constructive, insightful, detailed and generous help with earlier drafts of this article.

1. In some ways, this idea resonates with Derrida's (1992: 251-5) notion of the 'mystical foundation of authority'. He argues that the origin of authority (the making of law) is 'mystical' since it is provisional and cannot by definition rest upon anything but itself. The positing of law is therefore neither legal nor illegal in the founding moment, since it is founded on nothing absolute. Without a stable base, law can always be deconstructed, as evidenced by the decision that simultaneously preserves and destroys and suspends law in order to reinvent it in each case.

2. The case of the infamous and infinite 'war on terror', as well as its spatial manifestations in Abu Ghraib and Guantanamo Bay, makes clear that both Schmitt (in his critique of abstraction) and Agamben (in his critique of Schmitt's assertion of the separation between territoriality and the state) have a point.

3. However, as the case of Abu Ghraib shows, it is still not wise to create visual documents of this torture.

4. Edkins and Pin-Fat (2004: 13) argue that resistance to sovereign power - as it applies and subjects to human life - consists of a refusal to draw any lines between zoe and bios, inside and outside, human and inhuman.

5. Biometrics has been defined by the US Department of Homeland Security as 'a measurable, physical characteristic or personal behavioural trait used to recognize the identity or verify the claimed identity [of a person]' (CBC Online, 2004). Biometrics obliterate the arbitrariness of identity by transforming the 'individual' into representations of human body parts (fingerprints, facial features, retinas, irises) and digital data (mathematics, numbers, statistics).

6. The emergence of techno-hubs coincided with the point at which modernity reached what Virilio (1997) has termed its 'escape velocity', a threshold of speed beyond which the social collapses and can no longer hold itself together through any form of 'solidarity' (in the Durkheimian sense).

7. Indeed, as Keith and Pile (1993) argue, geography provides a remarkably effective structuring of socioeconomic inequality in spite of the frequent allusions to de-territorialization that are used to universalize the experience of a minority of 'global cosmopolitans'.

8. See Castells, who claims:

Experience by being related to spaces, becomes abstracted from power, and meaning is increasingly separated from knowledge. It follows a structural schizophrenia between two spatial logics that threatens to break down communication channels in society. The dominant tendency is toward a horizon of networked, a-historical, space of flows, aiming at imposing its logic over scattered, segmented places, increasingly unrelated to each other, less and less able to share cultural codes. Unless cultural and physical bridges are deliberately built between those two forms of space, we may be heading toward life in parallel universes whose times cannot meet because they are warped into different dimensions of social hyperspace. (1996: 428)

9. In popular media, the distinction between these two is often obliterated as both are tied to a singular somatic-racial deviation.

10. After the September 11 terror attacks in the United States, immigration officers in Canada, for example, are now authorized to arrest foreign nationals or permanent residents who (may) have breached the new Immigration and Refugee Protection Act. See: Canadian Border Services Agency (CBSA) Fact Sheet: http://www.cbsa-asfc.gc.ca/newsroom/factsheets/2004/0311ArrestsDetentions-e.pdf (consulted October 2005).

11. What matters here is that risks associated with mobility or, better, risks associated with the speed and fluidity of modernity, are conducive to forms of social intervention, social regulation and social engineering that deploy spatiality instrumentally as a means of reconfiguring the meaning of the body.

12. The fact that these two prima facie distinct logics seem to work well together supports Virilio's (1993) 
generic thesis that capitalism is an extension of pure war, in that it is inherently geared to further optimize the mobilization of the capacity to wage war (in terms of attuning logistics to ballistics).

13. This term refers to both those specific technologies (such as biometrics) and those state apparatuses (such as the criminal justice system) which are engaged in questioning the legitimacy of certain types of marked bodies (Magnet, forthcoming).

14. Originally designed for law enforcement, biometrics have been refined and their uses expanded over the last 20 years (Steinberg, 1993).

15. These categories may, of course, overlap.

16. Ironically, these fears may not be fully due to paranoia, given that, in at least one state, sensitive biometric information collected for welfare purposes has been shared with law enforcement officials.

17. In Welfare Realities: From Rhetoric to Reform, Mary Jo Bane and David Ellwood quoted a Director of Labour Relations in the Department of Public Welfare as saying: 'We've been trying to get the people who think like social workers out and the people who think like bank tellers in' (cited in Rogers-Dillon, 2004: $58)$.

18. Biometrics were introduced to welfare under the auspices of scientific testing. Hence LA's 'pilot project' was designed to test the following hypothesis: 'Will the addition of biometric technologies to welfare result in fraud reduction?' Yet this test-case only served to demonstrate the state's failure to comply with its own scientific processes. The audit described above was summarily rejected by the office of then-Governor Gray Davis. The Governor's office asserted that it was in 'disagreement with Governor's office cited no evidence to support the claim (Delsohn, 2003). Though science was invoked to justify the implementation of the programme, it was later disregarded during the review process. On the broader manipulation of science, see How the Laws of Physics Lie by Nancy Cartwright (1984) or Paula Treichler's work on the AIDS epidemic (1999).

19. The authors would like to thank one of the anonymous reviewers for their eloquent phrasing, which has been borrowed here.

\section{References}

Adelson, A. (1994) 'Electronic Fingerprinting is Growing but Pace Can Be Erratic', New York Times 31 May: 4.

Adey, P. (2007) “"May I Have Your Attention?” Airport Geographies of Spectatorship, Position and (Im)mobility', Environment and Planning D: Society and Space 25(3): 515-36.

Agamben, G. (1998) Homo Sacer: Sovereign Power and Bare Life. Stanford, CA: Stanford University Press.

Agamben, G. (1999) Remnants of Auschwitz. New York: Zone Books.

Agamben, G. (2005) State of Exception. Chicago, IL: University of Chicago Press.

Amoore, L. (2007) 'Vigilant Visualities: The Watchful Politics of the War on Terror', Security Dialogue 38: $215-32$.

Amoore, L. and M. DeGoede (2005) 'Governance, Risk and Dataveillance in the War on Terror', Crime, Law and Social Change 43: 149-73.

Augé, M. (1995) Non-places: An Introduction to an Anthropology of Supermodernity. London: Verso.

Beck, U. (1992) Risk Society: Towards a New Modernity. London: SAGE.

Bleich, E. (2005) 'The Legacies of History? Colonization and Immigrant Integration in Britain and France', Theory and Society 34: 171-95.

Butler, J. (2004) Precarious Life: The Powers of Mourning and Violence. London: Verso. 
Cartwright, N. (1984) How the Laws of Physics Lie. Oxford: Oxford University Press.

Castells, M. (1996) The Rise of the Network Society. Oxford: Blackwell.

CBC Online (2004) 'Biometrics: The Future of Security', CBC 14 December, URL (consulted March

2006): http://www.cbc.ca/news/background/airportsecurity/biometrics.html

Charlesworth, S. (2000) A Phenomenology of Working Class Experience. Cambridge: Cambridge

University Press.

Deleuze, G. (1995) Negotiations. New York: Columbia University Press.

Deleuze, G. (2001) Pure Immanence: Essays on a Life. New York: Zone Books.

Deleuze, G. and F. Guattari (1987) A Thousand Plateaus: Capitalism and Schizophrenia. Minneapolis, MN: University of Minnesota Press.

Delsohn, G. (2003) 'Audit Doubts Value of Welfare Fingerprinting: The Report Suggests the Program, Meant to Detect Cheaters, May Be Unnecessary', Sacramento Bee 3 January: A3.

Derrida, J. (1992) 'Force of Law: The "Mystical Foundation of Authority”', pp. 230-98 in Acts of

Religion. Cambridge, MA: Harvard University Press.

Douglas, M. (1984) Purity and Danger. London: Routledge.

Edkins, J. and V. Pin-Fat (2004) 'Introduction: Life, Power, Resistance', pp. 1-21 in J. Edkins, W. Pin-Fat and M. Shapiro (eds) Sovereign Lives: Power in Global Politics. New York: Routledge.

Eubanks, Virginia (2006) 'Technologies of Citizenship: Surveillance and Political Learning in the Welfare System', pp. 89-108 in Torin Monahan (ed.) Surveillance and Security: Technological

Politics and Power in Everyday Life. New York: Routledge.

Feldman, R.C. (2003) 'Considerations on the Emerging Implementation of Biometric Technology', Communication and Entertainment Law Journal 25, URL (consulted 9 May 2007):

http://ssrn.com/abstract=492444

Foucault, M. (1977) Discipline and Punish: The Birth of the Prison. New York: Vintage Books.

Foucault, M. (1978) History of Sexuality, Vol. I: The Will to Know. New York: Vintage.

Foucault, M. (1984) 'Space, Knowledge, and Power', pp. 239-56 in P. Rabinow (ed.) The Foucault Reader. Toronto: Random House.

Fuller, G. and R. Harley (2004) Aviopolis: A Book about Airports. London: Black Dog Publishing.

Gates, K. (2004) 'Our Biometric Future: The Social Construction of an Emerging Information Technology', dissertation, Institute of Communication Research, University of Illinois, UrbanaChampaign.

Gilliom, John (2001) Overseers of the Poor: Surveillance, Resistance, and the Limits of Privacy. Chicago, IL: University of Chicago Press.

Haraway, D. (1997) Modest_Witness@Second_Millennium: FemaleMan@_Meets_OncomouseTM. London: Routledge.

Keith, M. and S. Pile (eds) (1993) Place and the Politics of Identity. London: Routledge

Kohler-Hausmann, J. (2005) 'Workers and the "Welfare Queen": Criminalization and Surveillance through Welfare Policy during the 1970s'.

Le Corbusier (1971) The City of Tomorrow and its Planning. London: Architectural Press.

Lefebvre, H. (1991) The Production of Space. Oxford: Blackwell.

Lyon, D. (2003) Surveillance as Social Sorting. London: Routledge.

Lyon, D. (2007) Surveillance Studies: An Overview. Cambridge: Polity Press. 
Magnet, S. (forthcoming) 'Bio-benefits: Technologies of Criminalization, Biometrics and the Welfare System', in S. Hier and J. Greenberg (eds) Surveillance and Social Problems. Vancouver: UBC Press.

Monsebraaten, L. (1996) 'Fingerprints for Welfare Will 'Frighten” Mentally Ill', Toronto Star: A9.

Patterson, O. (1982) Slavery and Social Death: A Comparative Study. Cambridge, MA: Harvard University Press.

Pearman, H. (2004) Airports: A Century of Architecture. London: Lawrence King.

Powers, T. (2002) Intelligence Wars: American Secret History from Hitler to al-Qaeda. New York: New York Review Books.

Pratt, A. (2001) 'Sovereign Power, Carceral Conditions and Penal Practices: Detention and Deportation in Canada', Studies in Law, Politics, and Society 23: 43-78.

Roberts, D.E. (2002) Shattered Bonds: The Color of Child Welfare. New York: Basic Books.

Roderick, I. (1997) 'Household Sanitation and the Flow of Domestic Space', Space and Culture 1(1): 10536.

Rogers-Dillon, R. (2004) The Welfare Experiments: Politics and Policy Evaluation. Stanford, CA: Stanford Law and Politics.

Salter, M. (2007) 'Governmentalities of an Airport: Heterotopia and Confession', International Political Sociology 1(1): 49-66.

Schmitt, C. (1985) Political Theology: Four Chapters on the Concept of Sovereignty, trans. George D. Schwab. Boston, MA: MIT Press.

Schmitt, C. (2003) The Nomos of the Earth in the International Law of the Jus Publicum Europaeum. New York: Telos Press.

Shamir, R. (2005) 'Without Borders? Notes on Globalization as a Mobility Regime', Sociological Theory 23: $197-217$.

Sharp, L. (2000) 'The Commodification of the Body and its Parts', Annual Review of Anthropology 29: 287-328.

Simmel, G. (1948) 'The Metropolis and Mental Life', in Social Sciences III: Selections and Selected Readings, Vol. 2. Chicago, IL: University of Chicago Press.

Smith, A.M. (2007) Welfare Reform and Sexual Regulation. Cambridge: Cambridge University Press.

Steinberg, J. (1993) ‘Coming Soon: Fingerprints at Many Fingertips', New York Times 10 January: 6.

Treichler, P.A. (1999) How to Have Theory in an Epidemic: Cultural Chronicles of AIDS. Durham, NC:

Duke University Press.

Van Loon, J. (2002) Risk and Technological Culture: Towards a Sociology of Virulence. London:

Routledge.

Virilio, P. (1993) Pure War, with S. Lotringer. New York: Semiotext(e).

Virilio, P. (1997) Open Sky. London: Verso.

Wong, D.S. and F. Phillips (1995) 'Weld Wants Fingerprints in Aid Cases', The Boston Globe: 1.

Zhang, D. and A.K. Jain (2006) 'Advances in Biometrics', in Proceedings of the International Conference, ICB 2006, Hong Kong, China, 5-7 January.

Erin Kruger is a PhD Candidate in the Department of Sociology at the University of Alberta, Edmonton (Canada).

Shoshana Magnet is an AAUW Doctoral Candidate at the Institute of Communications Research at the University of Illinois at Urbana-Champaign (USA). 
Joost van Loon is Professor of Media Analysis at the Institute of Cultural Analysis of Nottingham Trent University (UK). 